\title{
Management of Xiphinema americanum and Soybean Severe Stunt in Soybean Using Crop Rotation
}

\author{
T. A. Evans, L. C. Miller, B. L. Vasilas, R. W. Taylor, and R. P. Mulrooney, Department of Plant and Soil Sci- \\ ences, University of Delaware, Newark 19717
}

\begin{abstract}
Evans, T. A., Miller, L. C., Vasilas, B. L., Taylor, R. W., and Mulrooney, R. P. 2007. Management of Xiphinema americanum and soybean severe stunt in soybean using crop rotation. Plant Dis. 91:216-219.

Soybean severe stunt (SSS), caused by the Soybean severe stunt virus (SSSV), is a soilborne virus disease affecting soybean (Glycine max) first described in Delaware in 1988. Lack of breeding programs directed at incorporating resistance to SSSV in new cultivar releases necessitated alternative methods of SSS control. The effect of crops in 2-year rotations on the dagger nematode (Xiphinema americanum), the putative nematode vector of SSSV, and SSS severity were examined. Two years of continuous corn or grain sorghum, wheat followed by 'HT-5203' soybean, or 2-year fallow, reduced both dagger nematode density in the soil and SSS severity. Crop rotation to the SSSV-tolerant HT-5203 soybean as a single crop for 2 years increased dagger nematode populations and SSS severity. Greenhouse studies indicated that corn, wheat, marigold, castor, and fallow treatments reduced dagger nematodes the most after 14 weeks compared with 'Essex' and HT 5203 soybean.
\end{abstract}

Soybean severe stunt (SSS) is a soilborne virus disease affecting soybean (Glycine max (L.) Merr.) in Delaware, first described in 1988 (13) and not reported elsewhere. Severely stunted plants with thickened, dark-green leaves that produce little or no yield have been observed for many years in Sussex County, DE, soybean plantings (5). In 1992, the disease was determined to be caused by the Soybean severe stunt virus (SSSV) (20). In the field, the disease occurs in localized, circular areas ranging from 10 to several hundred meters in diameter. It has been observed in many of the same fields year after year, particularly in those that have been cropped continuously with the susceptible soybean 'Essex' (20). Approximately 65 fields in Delaware are known to be affected by SSS and, as recently as 2005, soybean plants with SSS symptoms could be found in the field used in this experiment (T. A. Evans, personal observation). Symptomatic plants in the field are consistently associated with the dagger nematode, Xiphinema americanum Cobb (identification courtesy of A. M. Golden; voucher specimen in USDA Nematode Collection, Beltsville, MD) (7). Greenhouse studies with field soils from SSSaffected fields and infested with dagger

Corresponding author: T. A. Evans

E-mail: tomevans@udel.edu

Accepted for publication 15 September 2006.

DOI: 10.1094/PDIS-91-2-0216

(C) 2007 The American Phytopathological Society nematodes (10 to 20 per $250 \mathrm{~cm}^{3}$ soil) consistently resulted in SSS transmission and SSSV recovery from susceptible soybean cultivars, such as Essex (19). Nonviruliferous dagger nematodes at the same population densities in the field do not result in soybean damage (unpublished). To date, attempts to transmit SSSV using single nematodes in vitro have failed.

Field evaluations of soybean for SSSV resistance were conducted at the University of Delaware from 1988 to 1996 $(18,19)$. Many SSSV-resistant soybean cultivars have been identified, including 'Defiance', 'Delsoy 4710', 'Cisne', 'Chesapeake', and 'Stine S4650' (18). The susceptibility of Essex soybean and resistance of HT-5203 soybean to SSSV (20) were determined in 1989. Changing requirements of U.S. soybean growers have limited the availability of most of the resistant soybean cultivars mentioned above. Additionally, the lack of plant breeders working to incorporate SSSV resistance into new soybean cultivar releases has necessitated an alternative management strategy for SSS in Delaware this century.

Crop rotation has long been used to control soil populations of plant parasitic nematodes $(8,15-17)$. Plant parasitic nematodes require a living food base, and population densities of most species will decline to below the damage threshold if a field is planted without suitable host plants (6). Alternatively, some plant species may sustain or increase population density of these nematodes (3). In 1975, Hackney and Dickerson (11) reported that crops such as castor (Ricinus communis L.) or marigold (Tagetes erecta L.) reduced populations of both Meloidogyne incognita Kofoid \& White and Pratylenchus alleni Ferris nematodes. Georgi (10) and Miller (17) found cucumber (Cucumis sativus L.) and corn (Zea mays L.) to be poor hosts for the dagger nematode, but apple (Malus sylvestris Mill.) and dandelion (Taraxacum officinale Wiggers), which often increased dagger nematode populations, were considered good hosts.

This research was conducted to test the effect of crop species commonly used in rotation with soybean in Delaware and other plant species on dagger nematode populations in the greenhouse and field, and their effect on SSS severity in the field. The identification of resistant cultivars during the 1990s initially managed SSS such that information on how to manage it using crop rotation was not essential. The rapid change of soybean cultivars to Roundup Ready types, the lack of breeding to incorporate resistance to SSSV, and the limited U.S. acreage affected by this soilborne virus has left Delaware soybean growers without suitable SSSV-resistant cultivars. Soybean severe stunt continues to be a problem for a segment of Delaware soybean growers, and crop rotation is once again a timely disease management strategy.

\section{MATERIALS AND METHODS}

Field evaluation. A crop rotation study was conducted during the summers of 1989, 1990, and 1991 at Stockley, DE, in a field known to be severely affected by SSS during the summer of 1988 and to be infested with the dagger nematode. Five 3$\mathrm{cm}$-diameter soil cores collected from 4 to $20 \mathrm{~cm}$ below the soil surface were taken arbitrarily at four sites within each of the 24 field plots on 15 May 1989 to determine initial dagger nematode population densities. Dagger nematodes were isolated from each soil sample using a modified Baermann funnel system (2). Nematodes were separated from each $250 \mathrm{~cm}^{3}$ soil sample and concentrated by wet sieving through a $43-\mu \mathrm{m}$ sieve and collection on a $4.5-\mu \mathrm{m}$ sieve. Final concentrated solutions were placed onto Baermann funnels, covered to reduce evaporation, and maintained at 21 to $24^{\circ} \mathrm{C}$. Nematodes were collected daily over a 10-day period, and dagger nematodes were enumerated using a dissecting microscope at $\times 100$ magnification. Preplant populations of the dagger nematode were found to be uniformly distributed in the field plots and ranged from 12 to 17 per $250 \mathrm{~cm}^{3}$ of soil. 
Dagger nematode population densities were monitored over the course of the crop rotation study. Soil samples were collected on 15 October 1988, 1 June 1989, 15 August 1989, 3 October 1989, 2 June 1990, 2 August 1990, 1 October 1990, and 1 June 1991. Twenty 3-cm-diameter soil cores were taken at 4- to 20-cm depth arbitrarily from in-row locations within each plot. Samples for each plot were pooled, mixed to uniformity, and maintained at $4{ }^{\circ} \mathrm{C}$ until processing. Dagger nematode numbers were determined as previously described.

A randomized complete block design with four replications of $36 \mathrm{~m}^{2}$ plots was used. A 2-year rotation was selected, as local soybean production practices would preclude longer rotations. Rotations were the same during 1989 and 1990 and included continuous (single crop for 2 years) SSSV-susceptible Essex soybean, continuous SSSV-tolerant 'HT-5203' soybean, continuous 'Clark 787' corn, continuous 'Dekalb 424' grain sorghum, and 'Saluda' soft red winter wheat, followed by SSSVtolerant HT-5203 soybean (Table 1). In addition, plots were maintained fallow during the 2-year period.

Plots were established using local no-till practices (1). All plots received a burndown herbicide application of paraquat (Gramoxone, Ciba-Geigy now Syngenta) at $0.52 \mathrm{~kg}$ a.i. ha ${ }^{-1}$ plus surfactant 1 week before no-till planting and a preemergent herbicide, as indicated below, to control subsequent weeds. Continuous soybeans were planted in $38-\mathrm{cm}$ rows between 15 May and 5 June each year, and preemergent herbicides were applied with metolachlor (Dual, Ciba-Geigy now Syngenta) at $2.24 \mathrm{~kg}$ a.i. ha ${ }^{-1}$ and chloroimuron (Classic, DuPont Nemours) and linuron (Lorox, DuPont Nemours) at $0.36 \mathrm{~kg}$ a.i. $\mathrm{ha}^{-1}$. Corn was planted each year in $76-\mathrm{cm}$ rows between 21 May and 10 June and 10-34-0 liquid fertilizer applied at 57 liters $\mathrm{ha}^{-1}$. Corn plants were side dressed with $134 \mathrm{~kg}$ $\mathrm{N} \mathrm{ha}^{-1}$ as 30-0-0 urea ammonium nitrate (UAN) solution when they were $0.4 \mathrm{~m}$ tall. Weeds were controlled by preemergent applications of metolachlor at $2.24 \mathrm{~kg}$ a.i. $\mathrm{ha}^{-1}$ and atrazine at $1.68 \mathrm{~kg}$ a.i. ha ${ }^{-1}$. Continuous grain sorghum was planted in 38$\mathrm{cm}$ rows between 1 June and 7 June and side dressed with $80 \mathrm{~kg} \mathrm{~N}^{-1}$ as $30 \%$ UAN when plants were $0.3 \mathrm{~m}$ tall. Weeds were controlled with metolachlor and atrazine (AAtrex, Ciba-Geigy now Syngenta) at $0.56 \mathrm{~kg}$ a.i. ha ${ }^{-1}$. For doublecropped wheat, seeds were planted in 15$\mathrm{cm}$ rows by 1 November each year and harvested between 20 June and 4 July. Weeds were controlled with thifensulfuron methyl at $0.02 \mathrm{~kg}$ a.i. $\mathrm{ha}^{-1}$. Wheat received a broadcast application of $\mathrm{N}$ at $80 \mathrm{~kg} \mathrm{ha}^{-1}$ as $30 \%$ UAN during mid-March each year. Following wheat harvest, weeds were controlled with an application of glyphosate (Roundup, Monsanto) at $2.24 \mathrm{~kg}$ a.i. ha ${ }^{-1}$, and SSSV-tolerant HT-5203 soybean was planted by 10 July each year. Weeds were controlled in soybean with metolachlor at $2.24 \mathrm{~kg}$ a.i. $\mathrm{ha}^{-1}$.

For the third year of the rotation, all plots were planted with the SSSVsusceptible 'Essex' soybean on 16 May 1991. The outermost rows of each plot and $1 \mathrm{~m}$ of the end of each row were not used to minimize edge effects. Two months after seeding, the percentage of symptomatic plants in the final stand was recorded and is reported as the mean and standard error for each treatment.

In 1992, HT 5203 soybean was reevaluated to confirm its reaction to the virus. The cultivar evaluation was conducted at a site near Millsboro, DE, known to be heavily infested with the dagger nematode and SSS in 1991. Plots consisted of two 6.1-m-long rows spaced $38.1 \mathrm{~cm}$ apart. Seeds were sown at 20 per meter on 12 June. Each two-row plot was bordered by a single row of the SSSV-susceptible Essex soybean. The experimental design was a randomized complete block with four replications. The cultivars were rated on 24 July as highly susceptible, moderately susceptible, susceptible, tolerant, or resistant based on their symptom development and seed yield as follows. Highly susceptible cultivars exhibited severe stunting, had thick dark-green leaves and sometimes died within 4 weeks of emergence. Moderately susceptible cultivars were severely stunted but exhibited recovery and additional healthy growth late in the growing season. Susceptible cultivars exhibited mild stunting and necrosis. Tolerant cultivars exhibited very mild or no stunting, no necrosis, and produced a reasonable seed yield. Resistant cultivars exhibited no symptoms of virus infection (18).

On 24 July, 40 intact (including roots) Essex soybean plants exhibiting typical SSS symptoms were collected at random. Forty symptomless HT-5203 soybean plants in rows immediately adjacent to SSSV-infected Essex soybean plants also were collected. Plants were placed in individual plastic bags and maintained at $4^{\circ} \mathrm{C}$ until processing 1 day later. The SSSVinfection status of roots and leaves was determined separately for individual Essex and HT-5203 plants using a bioassay on the susceptible soybean cultivar Essex in the greenhouse (20). Samples were tritu- rated in $\mathrm{pH} 7.0$ sodium phosphate buffer $(0.01 \mathrm{M})$ and mechanically inoculated onto leaves of greenhouse grown Essex soybean seedlings at the unifoliate stage that had been previously dusted with Carborundum. Plants were observed for 2 weeks for typical SSS symptoms.

Greenhouse evaluation. During the winters of 1993 and 1994, the effect of plant host genotype on dagger nematode population was evaluated under greenhouse conditions. Two soybean cultivars, Essex (SSSV-susceptible) and HT-5203 (SSSV-tolerant), four crop species used in rotation with soybeans in the mid-Atlantic region of the United States, and four plant species previously noted for their ability to affect nematodes adversely were evaluated for their effect on dagger nematode populations under greenhouse conditions. Crop species included Clark 787 corn (Zea mays L.), Dekalb 424 sorghum (Sorghum bicolor (L.) Moench), 'Piper' sudangrass (Sorghum sudanense (Piper) Stapf), and Saluda wheat (Triticum aestivum L.). Other species evaluated included 'Mary Washington' asparagus (Asparagus officinalis L.), canola (Brassica napus L.), 'Hale' castor (Ricinus communis), and 'Sparky' marigold (Tagetes erecta).

An Arendtsville gravel loam soil (fineloamy, mixed, semiactive, mesic Typic Hapludults) heavily infested with dagger nematodes (soil courtesy of J. M. Halbrendt, Pennsylvania State University, Bigglerville) was bait-tested to determine whether Tomato ringspot virus (TmRSV) was present in the population using the method previously described by Hoy et al. (12). The soil was from a Pennsylvania peach orchard, and there was a possibility that the dagger nematodes could be contaminated by TmRSV. Soil containing nonviruliferous dagger nematodes was mixed to uniformity on a washed concrete floor. Three $250 \mathrm{~cm}^{3}$ aliquots of soil were taken at random and processed by wet sieving and sucrose flotation (13) to extract dagger nematodes. Nematodes were separated from organic matter and concentrated by wet sieving as previously described. Filtrates were centrifuged for 5 $\min$ at $500 \times g$, and pellets were resuspended with a $13.2 \%$ sucrose solution (132 $\mathrm{g}$ liter $^{-1}$ ) and centrifuged for $1 \mathrm{~min}$ at $500 \times$ $g$. The supernatant was decanted and fil-

Table 1. The 2-year rotation treatments for management of dagger nematodes (Xiphinema americanum) and soybean severe stunt disease in soybean

\begin{tabular}{lll}
\hline & \multicolumn{2}{c}{ Crop rotation treatment description } \\
\cline { 2 - 3 } Treatment & \multicolumn{1}{c}{ Year 1 } & \multicolumn{1}{c}{ Year 2 } \\
\hline $\mathrm{A}$ & Fallow & Fallow \\
$\mathrm{B}$ & Essex soybean & Essex soybean \\
$\mathrm{C}$ & HT-5203 soybean & HT-5203 soybean \\
$\mathrm{D}$ & Saluda wheat then HT-5203 soybean & Saluda wheat then HT-5203 soybean \\
$\mathrm{E}$ & Dekalb 424 grain sorghum & Dekalb 424 grain sorghum \\
$\mathrm{F}$ & Clark 787 corn & Clark 787 corn \\
\hline
\end{tabular}

y Soybean severe stunt susceptible soybean cultivar.

z Soybean severe stunt tolerant soybean cultivar. 
tered through a 43- $\mu \mathrm{m}$ sieve and nematodes captured on a $4.5-\mu \mathrm{m}$ sieve. Dagger nematode number was adjusted to 12.5 per $250 \mathrm{~cm}^{3}\left(25\right.$ per $\left.500 \mathrm{~cm}^{3}\right)$ of soil by mixing the gravel loam soil to uniformity with an Evesboro loamy sand (Mesic, coated Lamellic Quartzipsamments) 1 week after it had been pasteurized at $121^{\circ} \mathrm{C}$ for $1 \mathrm{~h}$ on

White, plastic 15.2-cm-diameter pots were filled with $500 \mathrm{~cm}^{3}$ of the soil mixture infested with 25 dagger nematodes, and then six seeds of each species were planted in each of six pots. Six pots of the soil mixture were not planted and maintained as controls. Seedlings in each pot were thinned to one after emergence. Treatments were completely randomized and maintained in a greenhouse with a 16-h 2 consecutive days.

photoperiod at 24 to $28^{\circ} \mathrm{C}$. Exfoliated vermiculite was placed around pots to minimize heating of the soil by direct sunlight. Plants were watered lightly as needed. At 14 weeks after planting, the soil in each pot was removed and dagger nematodes were extracted by wet sieving and sucrose flotation as previously described. Dagger nematode number was enumerated using a dissecting microscope and expressed as dagger nematodes per $250 \mathrm{~cm}^{3}$. The experiment was repeated once.

\section{RESULTS AND DISCUSSION}

Field evaluation. The soil population of dagger nematodes was reduced after 2 years of continuous corn, sorghum, wheat, then HT-5203 soybean or fallow conditions (Fig. 1). Essex and HT-5203 soybeans

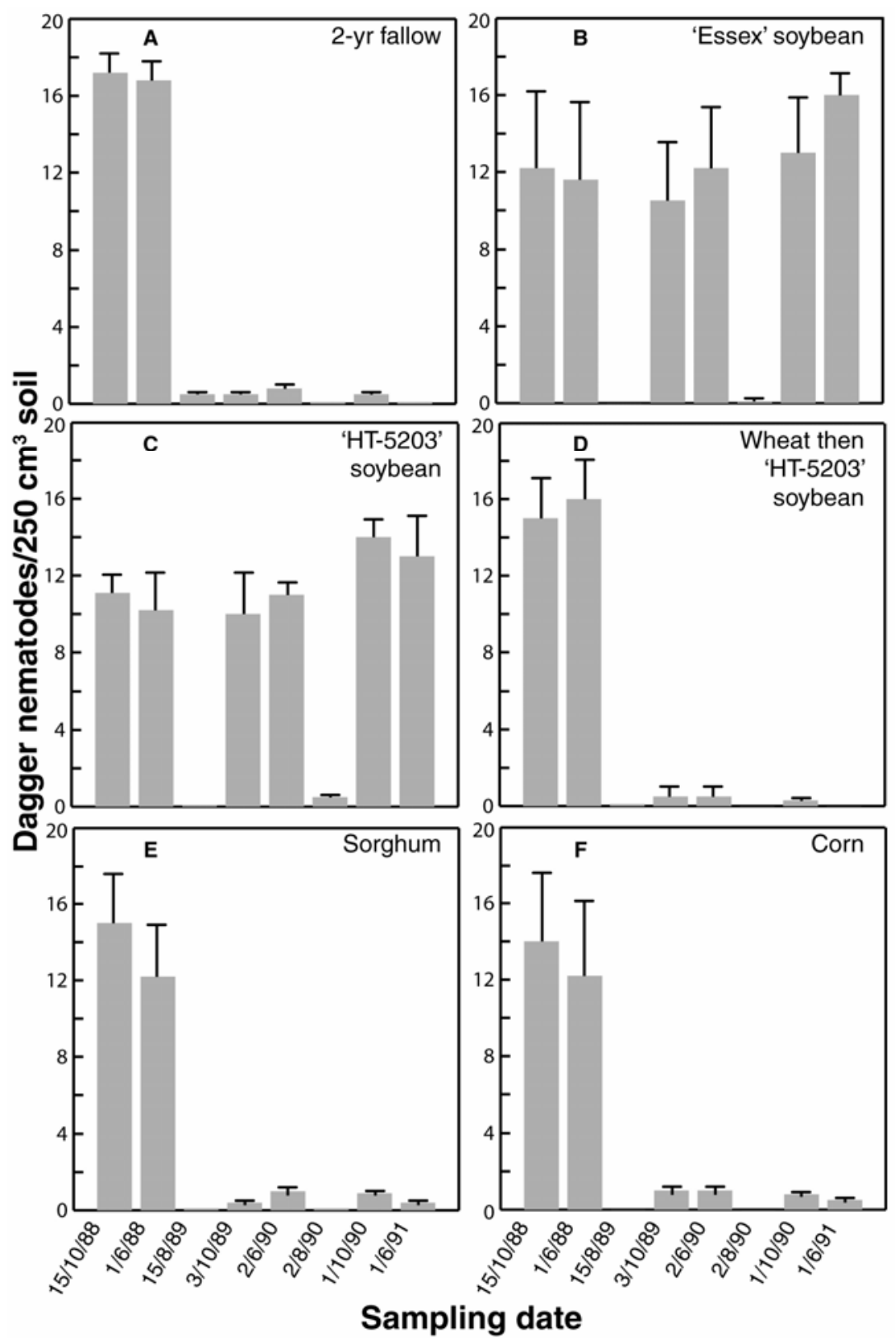

Fig. 1. Effect of 2-year crop rotation of different plant species on dagger nematode (Xiphinema americanum) population density in the field. Crop rotation treatments were fallow (A), 'Essex' soybean (B), 'HT-5203' soybean (C), 'Saluda' wheat then 'HT-5203' soybean (D), 'DeKalb 424' grain sorghum (E), and 'Clark 787' corn (F). Each value is the mean of four replicates, and bars represent the standard error. provided the best hosts for dagger nematodes, resulting in the highest population after the 2-year rotation. A 2-year rotation away from soybean is the longest rotation acceptable to Delaware growers. For soybean, regardless of virus-susceptibility, the dagger nematode populations were highest each June and declined each August as expected (9) when soil temperature reached its maximum (14). By October of each year, when soil temperatures decreased, dagger nematode population densities increased to June levels. There was no significant difference in dagger nematode population density before or after 2year rotation to SSSV-susceptible or SSSV-tolerant soybean cultivars.

During the third year, when rotation plots were planted to SSSV-susceptible Essex soybean, the SSS index value was greatest for plots previously planted with HT-5203 soybean (82\%), and second highest for plots continuously planted with Essex soybean (32\%) (Fig. 2). Continuous grain sorghum, corn, or wheat then HT5203 soybean resulted in lower disease indices of 12,10 , and $8 \%$, respectively. The double crop of tolerant soybean grown after wheat may be effective in reducing both dagger nematode populations and future SSS severity. We believe that the HT-5203 soybean avoided being parasitized by viruliferous dagger nematodes because soil populations were lowest at the early July planting date (Fig. 1C and D), thereby resulting in the second lowest percent infection (Fig. 2). Plots maintained fallow for 2 consecutive years had the lowest percent infection (2\%); however, fallow systems are financially unacceptable to Delaware soybean growers.

The 1992 soybean cultivar evaluation for SSSV resistance provided an answer to the increased SSS incidence after a 2-year rotation to HT-5203 soybean (Fig. 2). Essex soybean was confirmed to be highly SSSV susceptible, and HT-5203 soybean was confirmed to be SSSV tolerant. The roots, but not the leaves, of $75 \%$ of HT-5203 soybean plants tested were determined by bioassay to be SSSV infected. The leaves of $100 \%$ of Essex soybean immediately adjacent to the HT-5203 plants were confirmed to be SSSV infected. The resulting infection of HT-5203 is latent, and the yield of infected plants is not greatly diminished (19). The roots of HT-5203 soybean are a good host for the dagger nematode (Fig. 1C) and a good host for SSSV (Fig. 2). The inability of SSSV to move from the roots of HT-5203 soybean to its leaves resulted in only small yield reductions and hence SSS tolerance. In an earlier study by Bergeson et al., a strain of Tobacco ringspot virus was transmitted by viruliferous dagger nematodes to the roots of certain soybean cultivars but rarely moved to leaves (4).

The results of this crop rotation study suggest that SSS severity can be reduced markedly by a 2-year rotation to corn, grain 
sorghum, or 'Saluda' wheat followed by HT-5203 soybean. These rotations are acceptable to soybean growers in the midAtlantic region of the United States and are cost effective. Rotation to a single crop of SSSV-resistant soybean cultivars (18) may provide SSS control for growers that are unwilling or unable to rotate to other crops. Further rotation studies are necessary to verify the effectiveness of using longer rotations to SSS-resistant soybean cultivars to reduce viruliferous dagger nematode populations and hence SSS severity in the field.

Greenhouse evaluation. When soil containing nonviruliferous dagger nematodes was planted to SSSV-resistant or tolerant soybean, grain sorghum, corn, wheat, canola, asparagus, marigold, castor, or sudangrass or left fallow, dagger nematode populations 14 weeks later were significantly lower than those in the initial

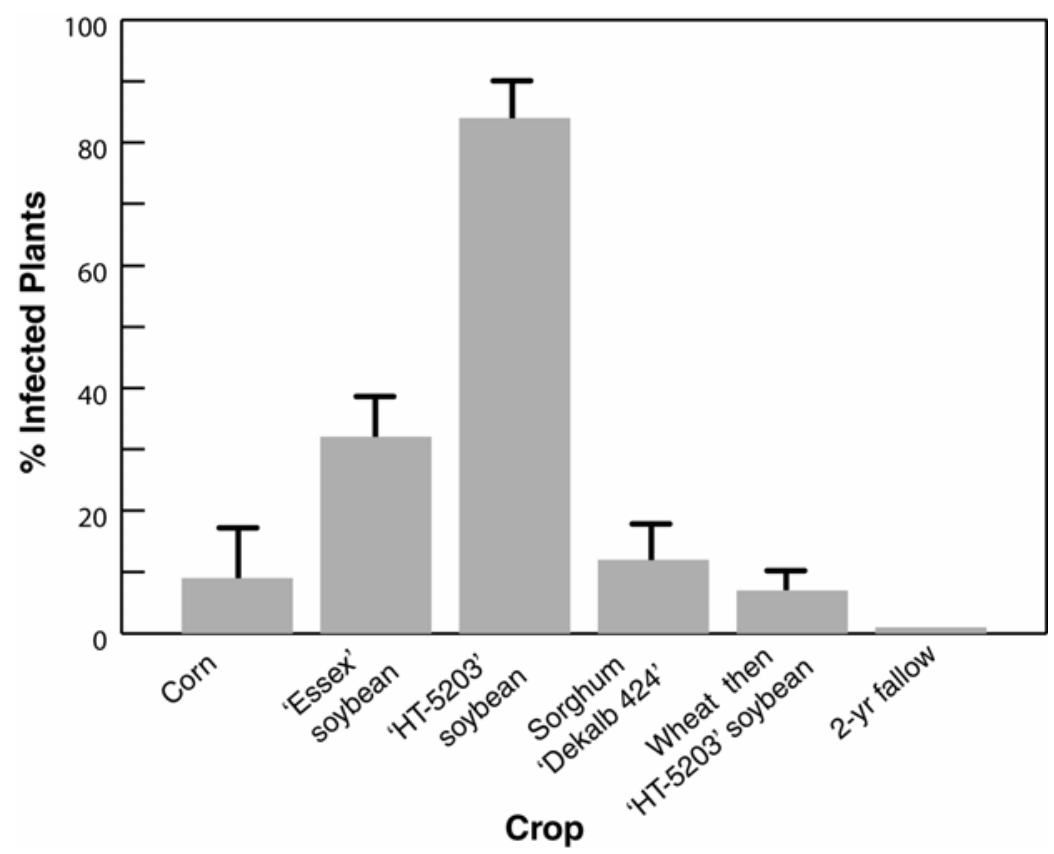

Fig. 2. Effect of 2-year crop rotational plant species on the severity of soybean severe stunt disease in 'Essex' soybean during the third year in the field. The disease index value represents the percentage of infected or symptomatic plants of the total number of plants in the final stand. Each value is the mean of four replicates, and bars represent the standard error.

Table 2. Effect of plant species on dagger nematode (Xiphinema americanum) survival under greenhouse conditions

\begin{tabular}{llcc}
\hline & & \multicolumn{2}{c}{$\begin{array}{c}\text { Dagger nematode number } \\
\text { per } \mathbf{2 5 0} \mathbf{~ c m}^{\mathbf{3}} \text { soil after 14 weeks }\end{array}$} \\
\cline { 3 - 4 } Plant species & Common name & $\mathbf{1 9 9 3}$ & $\mathbf{1 9 9 4}$ \\
\hline Glycine max 'Essex' & Soybean & $10.2 \mathrm{a}^{\mathrm{z}}$ & $12.1 \mathrm{a}$ \\
Glycine max 'HT-5203' & Soybean & $7.9 \mathrm{~b}$ & $8.5 \mathrm{~b}$ \\
Brassica napus & Canola & $6.9 \mathrm{~b}$ & $10.1 \mathrm{~b}$ \\
Asparagus officinalis 'Mary Washington' & Asparagus & $4.2 \mathrm{bc}$ & $8.7 \mathrm{~b}$ \\
Sorghum sudanense 'Piper' & Sudangrass & $4.1 \mathrm{~b}$ & $7.4 \mathrm{~b}$ \\
Sorghum bicolor 'DeKalb 424 & Sorghum & $4.1 \mathrm{~b}$ & $3.1 \mathrm{~cd}$ \\
Triticum aestivum 'Saluda' & Wheat & $1.3 \mathrm{~d}$ & $2.5 \mathrm{~d}$ \\
Tagetes erecta 'Sparky' & Marigold & $1.0 \mathrm{~d}$ & $1.5 \mathrm{~d}$ \\
Zea mays 'Clark 787' & Corn & $0.4 \mathrm{~d}$ & $1.0 \mathrm{~d}$ \\
Ricinus communis 'Hale' & Castor & $0.4 \mathrm{~d}$ & $1.7 \mathrm{~d}$ \\
Fallow & & $1.3 \mathrm{~d}$ & $2.2 \mathrm{~d}$ \\
\hline
\end{tabular}

${ }^{y}$ Initial population of dagger nematodes was 12.5 per $250 \mathrm{~cm}^{3}\left(25\right.$ per $\left.500 \mathrm{~cm}^{3}\right)$.

${ }^{\mathrm{z}}$ Means in a column followed by the same letter are not significantly different (Fisher's LSD $P \leq 0.05$ ).
LITERATURE CITED

1. Anonymous. 1990. Pest management recommendations for field crops. Cooperative Extension Service, University of Maryland and University of Delaware. Bull. 237.

2. Barker, K. R. 1985. An advanced treatise on Meloidogyne. Vol. II: Methodology. North Carolina State University and the Agency for International Development. N.C. State University Graphics, Raleigh.

3. Barker, K. R., and Nusbaum, C. J. 1971. Diagnostic and advisory programs. Pages 281-301 in: Plant Parasitic Nematodes. Vol. I: Morphology, Anatomy, Taxonomy, and Ecology. B. M. Zuckerman, W. F. Mai, and R. A. Rhode, eds. Academic Press, New York.

4. Bergeson, G. B., Athow, K. L., Laviolette, F. A., and Thomasine, M. 1964. Transmission, movement, and vector relationship of tobacco ringspot virus in soybean. Phytopathology 54:723-728.

5. Crittenden, H. W., Hastings, K. M., and Moore, D. M. 1966. Soybean losses caused by tobacco ringspot viruses. Plant Dis. Rep. 50:910-913.

6. Dropkin, V. H. 1980. Introduction to Plant Nematology. John Wiley \& Sons, New York.

7. Evans, T. A. 1999. Nepoviruses: Soybean severe stunt. Pages 65-66 in: Compendium of Soybean Diseases. 4th ed. American Phytopathological Society, St. Paul, MN.

8. Everts, K. L., Sardanelli, S., Kratochvil, R. J. Armentrout, D. K., and Gallagher, L. E. 2006 Root-knot and root-lesion nematode suppression by cover crops, poultry litter, and poultry litter compost. Plant Dis. 90:487-492.

9. Flegg, J. J. M. 1968. Life-cycle studies of some Xiphinema and Longidorus species in Southeastern England. Nematologica 14:197-210.

10. Georgi, L. L. 1988. Effect of three plant species on population densities of Xiphinema americanum and $X$. rivesi. J. Nematol. 20:474-477.

11. Hackney, R. W., and Dickerson, O. J. 1975. Marigold, castor bean, and chrysanthemum as controls of Meloidogyne incognita and Pratylenchus alleni. J. Nematol. 7:84-89.

12. Hoy, J. W., Miretich, S. M., and Lownsbery, B. F. 1984. Differential transmission of Prunus tomato ringspot virus strains by Xiphinema californicum. Phytopathology 74:332-335.

13. Jenkins, W. R. 1964. A rapid centrifugalflotation technique for separating nematodes from soil. Plant Dis. Rep. 48:692.

14. Lownsbery, B. F., and Maggenti, A. R. 1963. Some effects of soil temperature and soil moisture on population levels of Xiphinema americanum. Phytopathology 53:667-668.

15. MacGuidwin, A. E., and Layne, T. L. 1995. Response of nematode communities to sudangrass and sorghum-sudangrass hybrids grown as green manure crops. Suppl. J. Nematol. 27(4S):609-616.

16. McSorley, R., and Gallaher, R. N. 1993. Population dynamics of plant parasitic nematodes on cover crops of corn and sorghum. J. Nematol. 25:446-453.

17. Miller, P. M. 1980. Reproduction and survival of Xiphinema americanum on selected woody plants, crops, and weeds. Plant Dis. 64:174175.

18. Mulrooney, R.P., Evans, T.A., and Taylor, R.W. 1997. Evaluation of selected soybean cultivars for resistance to soybean severe stunt virus, 1996. Biological and Cultural Control Tests. Vol. 12:84 The American Phytopathological Society, St Paul, MN

19. Weldekidan, T. 1989. A new virus disease of soybeans in Delaware. M.S. thesis. University of Delaware, Newark.

20. Weldekidan, T., Evans, T. A., Carroll, R. B. and Mulrooney, R. P. 1992. Etiology of soybean severe stunt and some properties of the causal virus. Plant Dis. 76:747-750. 